\title{
Association of Xmn I Polymorphism and Hemoglobin E Haplotypes on Postnatal Gamma Globin Gene Expression in Homozygous Hemoglobin E
}

\author{
Supachai Ekwattanakit, ${ }^{1}$ Yuwarat Monteerarat, ${ }^{1}$ Suchada Riolueang, ${ }^{1,2}$ \\ Kalaya Tachavanich, ${ }^{3}$ and Vip Viprakasit ${ }^{2,3}$ \\ ${ }^{1}$ Graduate Program and Medical Scholar Program in Immunology, Department of Immunology, Faculty of Medicine Siriraj Hospital, \\ Mahidol University, 2 Prannok Road, Bangkok Noi, Bangkok 10700, Thailand \\ ${ }^{2}$ Thalassemia Center, Faculty of Medicine Siriraj Hospital, Mahidol University, 2 Prannok Road, Bangkok Noi, \\ Bangkok 10700, Thailand \\ ${ }^{3}$ Hematology/Oncology Division, Department of Pediatrics, Faculty of Medicine Siriraj Hospital, Mahidol University, 2 Prannok Road, \\ Bangkok Noi, Bangkok 10700, Thailand
}

Correspondence should be addressed to Vip Viprakasit, sivvp@mahidol.ac.th

Received 30 April 2012; Accepted 14 August 2012

Academic Editor: Samir K. Ballas

Copyright (C) 2012 Supachai Ekwattanakit et al. This is an open access article distributed under the Creative Commons Attribution License, which permits unrestricted use, distribution, and reproduction in any medium, provided the original work is properly cited.

\begin{abstract}
Background and Objectives. To explore the role of cis-regulatory sequences within the $\beta$ globin gene cluster at chromosome 11 on human $\gamma$ globin gene expression related to $\mathrm{Hb} \mathrm{E}$ allele, we analyze baseline hematological data and $\mathrm{Hb} \mathrm{F}$ values together with $\beta$ globin haplotypes in homozygous Hb E. Patients and Methods. 80 individuals with molecularly confirmed homozygous Hb E were analyzed for the $\beta$ globin haplotypes and Xmn I polymorphism using PCR-RFLPs. 74 individuals with complete laboratory data were further studied for association analyses. Results. Eight different $\beta$ globin haplotypes were found linked to Hb E alleles; three major haplotypes were (a) (III), (b) (V), and (c) (IV) accounting for 94\% of Hb E chromosomes. A new haplotype (Th-1) was identified and most likely converted from the major ones. The majority of individuals had $\mathrm{Hb} F<5 \%$; only $10.8 \%$ of homozygous $\mathrm{Hb}$ E had high $\mathrm{Hb} \mathrm{F}$ (average 10.5\%, range 5.8-14.3\%). No association was found on a specific haplotype or Xmn I in these individuals with high $\mathrm{Hb}$, measured by alkaline denaturation. Conclusion. The cis-regulation of $\gamma$ globin gene expression might not be apparent under a milder condition with lesser globin imbalance such as homozygous Hb E.
\end{abstract}

\section{Introduction}

Beside producing abnormal variant, hemoglobin $\mathrm{E}(\mathrm{HbE})$, the $\mathrm{G} \rightarrow$ A substitution in codon 26 (Glu $\rightarrow$ Lys) of the $\beta$ globin gene $\left(\beta^{\mathrm{E}}\right)$ could also produce $\beta^{+}$thalassemia due to decreased functional $\mathrm{HbE}$-mRNA, secondary to alternative splicing mechanism [1]. However, the clinical phenotype in homozygous $\mathrm{Hb} \mathrm{E}(\mathrm{Hb} \mathrm{EE})$ is rather asymptomatic with very mild anemia. In contrast, patients with $\mathrm{HbE} / \beta$ thalassemia have a more diverse clinical phenotype from transfusion dependent to very mild disease [2-5]. Although, understanding of clinical phenotypic diversity in patients with $\mathrm{Hb} \mathrm{E} / \beta$ thalassemia has long been a topic of several investigations, at present, the genotype-phenotype correlation of this so-called single gene disorder remains obscure.

Variation of postnatal $\gamma$ globin expression and $\mathrm{HbF}$ production in these patients was thought to be one of the main genetic factors responsible for clinical heterogeneity found in $\mathrm{Hb} \mathrm{E} / \beta$ thalassemia by reducing globin imbalance and ameliorating ineffective erythropoiesis. Through erythroid development, the $\gamma$ globin expression was regulated by interactions between cis-acting sequences within the $\beta$ globin cluster and trans-acting factors such as BCL-11A, cMYB, and TOX $[1,6-8]$. The most significant genetic factor in cis associated with high $\mathrm{HbF}$ is Xmn I polymorphism located at -158 upstream to the ${ }^{\mathrm{G}} \gamma$ globin genes [9]. In a recent study 
using a more refined SNP analysis of the $\beta$ globin gene cluster in $\mathrm{HbE} / \beta$ thalassemia has shown that there was no other variant elsewhere which has a comparable level of association with that of Xmn I site and the T allele $(X m n \mathrm{I},+)$ was almost always in cis with the $\mathrm{HbE}$ alleles [10]. To further explore the role of cis-acting sequences on $\mathrm{Hb} F$ production under the less hematopoietic stress and globin chain imbalance in $\mathrm{Hb} \mathrm{E}$ disorders, we analyzed 7 known single nucleotide polymorphisms within the $50 \mathrm{~kb}$ of the $\beta$ globin gene cluster to construct $\mathrm{Hb}$ E-linked $\beta$ globin haplotypes together with $X m n$ I polymorphism. The $\beta$ globin haplotypes of $\mathrm{Hb} \mathrm{E}$ have been characterized previously in Thailand and within the region of Southeast Asia but they were principally utilized to identify origin, spread, and anthropology of different ethnic groups found with $\mathrm{Hb}$ E [11-13]. However there were no study to correlate such findings with postnatal production of $\mathrm{Hb} \mathrm{F}$. Recently, we have extensively analyzed up to 76 Thai individuals with $\mathrm{Hb} \mathrm{E}$ [14] and identified several cases with significantly high $\mathrm{Hb}$ F levels in their steady stage and several of them had persistently high $\mathrm{Hb}$ F during the followup period. Therefore, these individuals provide a different model to explore the role of the $\beta$ globin haplotypes and $X m n$ I (representing cis-regulatory sequences) on propensity of the $\gamma$ globin expression. Moreover the association analysis between $\mathrm{Hb} \mathrm{E}$ alleles and persisting $\mathrm{Hb} \mathrm{F}$ production in our Thai population might be useful to confirm the findings and apply in a more clinical significant syndrome such as $\mathrm{Hb} \mathrm{E} / \beta$ thalassemia.

\section{Materials and Methods}

Ethylene diamine tetraacetic acid (EDTA) blood was obtained from 80 Thai individuals with homozygous $\mathrm{HbE}$ after informed consent. They were parents, siblings, and unrelated individuals who were tested due to microcytic anemia at Department of Pediatrics, Faculty of Medicine Siriraj Hospital as a part of an ongoing project studying natural history and genotype-phenotype correlation in $\mathrm{Hb}$ E disorders in Thailand. This study was approved by a local ethical committee at Mahidol University. Complete hematological and hemoglobin studies have been performed using standard techniques as described previously [14]. Quantification of $\mathrm{Hb} \mathrm{E}$ and $\mathrm{Hb} \mathrm{F} \%$ was performed by calculation from cellulose acetate electrophoresis and for $\mathrm{Hb}$ $\mathrm{F}$, it was subsequently confirmed by alkaline denaturation method [15].

2.1. Molecular Diagnosis of Homozygous $\mathrm{Hb}$ E by PCRRestriction Fragment Length Polymorphism (RFLP). Genomic DNA was extracted using the standard phenol/chloroform procedure. Genotype of homozygous $\mathrm{Hb} \mathrm{E}$ was confirmed in every case at the molecular level. PCR amplified a fragment of $427 \mathrm{bp}$ in which it contains two $\mathrm{Mnl}$ I restriction sites, one at the $5^{\prime}$ end used as an internal control for digestion (135 bp) and another one linked to CD26 (171 and $62 \mathrm{bp}$ ). Subsequently we digested the PCR products using $M n l$ I using the conditions recommended by the manufacturer (New England Biolabs, Beverly, MA); Hb E

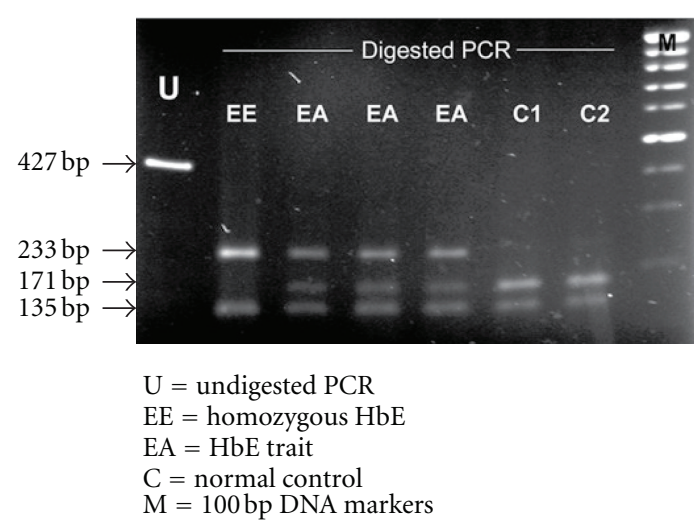

Figure 1: Molecular analysis of HbE mutation using PCR-RFLP by $\mathrm{Mnl}$ I digestion.

mutation $(\mathrm{G} \rightarrow \mathrm{A})$ abolishes this $\mathrm{Mnl}$ I site therefore digestion demonstrated the $233 \mathrm{bp}$ and $135 \mathrm{bp}$ (internal control) (as shown in Figure 1). Further details of this molecular testing have been described elsewhere [14].

2.2. $\beta$ Globin Gene Haplotypes and Frameworks by PCRRFLPs. PCR amplifications were carried out by using the pairs of primers under the optimal conditions as previously described [16]. PCR-based RFLPs covering 7 enzymatic restriction sites across $50 \mathrm{~kb}$ of the $\beta$-globin gene cluster were amplified from the regions $\varepsilon,{ }^{\mathrm{G}} \gamma,{ }^{\mathrm{A}} \gamma, 5^{\prime} \varphi \beta, 3^{\prime} \varphi \beta, 5^{\prime} \beta$, and $3^{\prime} \beta$ and were subsequently digested with HindII, HindIII, HindIII, HindII, HindII, AvaII, and HinfI, respectively, to identify nucleotide substitutions within and around the $\beta$ globin gene cluster [16]. Haplotypes and frameworks were designated based on the presence $(+)$ or absence $(-)$ of all these restriction sites; two PCR-RFLP sites of the AvaII in the intron- 2 of the $\beta$ globin gene and of the BamHI located $3^{\prime}$ to the $\beta$ globin gene were used to identify the frameworks. In addition, the Xmn I polymorphic site was genotyped by the same technique. The haplotype analysis was performed by using the Phase-Standard-analysis version 2.1.2 [17, 18] to construct $\mathrm{Hb}$ E-linked haplotypes. Haplotypes with a low frequency $(<0.5 \%)$ were excluded from further analyses.

2.3. Statistical Analysis. SPSS statistical software package Version 10.0 (SPSS Inc., 2000) was used for data analysis. Paired and unpaired $t$-tests were used to determine the differences between groups. $P$ values $(P)$ less than 0.05 were considered to be statistically significant.

\section{Results}

From 80 individuals with homozygous $\mathrm{Hb} \mathrm{E}$, we could successfully genotypes all 8 polymorphic sites in 77 cases (154 chromosomes of $\mathrm{Hb} \mathrm{E}$, Table 1). These individuals were mainly from Bangkok and the Central plain of Thailand. Eight different $\beta$ globin haplotypes associated with $\mathrm{HbE}$ alleles have been constructed with two novel ones, (- - - $+-)$ and $(++-+++-)$. Three major haplotypes based 
TABLE 1: Summary of 8 different $\beta$ globin haplotypes linked to $\mathrm{Hb}$ E alleles from $154 \mathrm{Hb}$ E chromosomes.

\begin{tabular}{|c|c|c|c|c|c|c|c|c|c|c|}
\hline \multirow{2}{*}{ Number } & \multicolumn{8}{|c|}{$\beta$-globin haplotypes } & \multirow{2}{*}{$X m n$ I } & \multirow{2}{*}{$\begin{array}{c}\text { Total } \\
N=154(\%)\end{array}$} \\
\hline & Annotations & $\varepsilon$ HindII & $\mathrm{G}_{\gamma}$ HindIII & $\mathrm{A}_{\gamma}$ HindIII & $5^{\prime} \beta \varphi$ HindII & $3^{\prime} \beta \varphi$ HindII & $5^{\prime} \beta$ AvaII & $3^{\prime} \beta$ HinfI & & \\
\hline (1) & (a) or III & - & + & - & + & + & + & - & + & $93(60.39)$ \\
\hline (2) & (b) or V & + & - & - & - & - & + & - & - & $37(24.02)$ \\
\hline (3) & (c) or IV & - & + & - & + & + & - & + & + & $15(9.74)$ \\
\hline (4) & Y1 & - & + & - & - & + & + & - & - & $4(2.60)$ \\
\hline (5) & VIII & - & + & - & + & - & + & - & + & $1(0.65)$ \\
\hline (6) & $\mathrm{Y} 2$ & - & + & + & - & + & + & - & - & $2(1.30)$ \\
\hline (7) & Th-1 & - & - & - & - & - & + & - & - & $1(0.65)$ \\
\hline (8) & Arab-Indian & + & + & - & + & + & + & - & + & $1(0.65)$ \\
\hline
\end{tabular}

(a), (b), and (c) were based on Antonarakis et al., 1982 [13]. III, V, IV, and VIII were based on Orkin et al., 1982 [19]. Y1 and Y2 were based on Yongvanit et al., 1989 [12]. Th-1 is a novel $\beta$ globin haplotype found in this study. Arab-Indian haplotype was based on Nagel and Ranney, 1990 [20].

on Orkin et al. [19] III (60.4\%), V (24.0\%), and IV (9.7\%) were accounted for the majority of $\mathrm{HbE}$ alleles and they were linked with Xmn I +, - , and +, respectively. Therefore only $71.43 \%$ of $\mathrm{HbE}$ allele is linked with the $\mathrm{T}$ allele (or + genotype) of Xmn I. Only the frameworks $2(+-)$ and 3 ($+)$ based on Antonarakis et al. [13] were found, while the framework associated with $(--)$ or $(++)$ patterns were not observed. The summary of all eight $\beta$ globin haplotypes is shown in Table 1.

Seventy-four individuals who had all complete hematological and hemoglobin data with molecular results including $\mathrm{Hb} \mathrm{E}$ genotypes and their linked $\beta$ globin haplotypes were subjects for the further association analyses. Detailed hematological and clinical data of these individuals have been described previously [14]. In summary, majority of homozygous $\mathrm{Hb} \mathrm{E}$ cases have borderline hemoglobin $(\mathrm{Hb})$ and hematocrit (Hct) levels with significantly low mean corpuscular volume (MCV $58 \pm 5.2 \mathrm{fL})$. The levels of baseline hemoglobin were highest in male subjects (12.6 \pm $1 \mathrm{~g} / \mathrm{dL})$ followed by females $(11.4 \pm 1 \mathrm{~g} / \mathrm{dL})$, and pediatric cases $(10.6 \pm 0.8 \mathrm{~g} / \mathrm{dL})$. None of these individuals had hepatosplenomegaly and require blood transfusion [14]. At the beginning of the study, 12 individuals were identified with high $\mathrm{Hb} \mathrm{F}$ over $5 \%$ at their steady stage. During our follow-up, $\mathrm{Hb} \mathrm{F}$ levels in 4 pediatric cases (under 15 years) decreased or were absent. This finding suggests that increase of $\mathrm{Hb} \mathrm{F}$ levels in some pediatric individuals with homozygous $\mathrm{Hb} \mathrm{E}$ might be resulted from persistent postnatal production of $\gamma$ globin expression in which declined later on in their late childhood [6]. While in adult cases, their $\mathrm{Hb} \mathrm{F}$ levels remained persistently high excluding the possibility of temporary hematopoietic stress that might affect the expression of the $\gamma$ globin genes. These eight individuals with homozygous $\mathrm{Hb} \mathrm{E}(10.8 \%)$ had high level of $\mathrm{Hb} \mathrm{F}$ (average 10.5\%, range 5.8-14.3\%), while the rest had $\mathrm{Hb} \mathrm{F}$ less than 5\%. Distribution of steady stage $\mathrm{Hb}$ $\mathrm{F}$ percentages in all 74 homozygous $\mathrm{Hb} \mathrm{E}$ is shown in Figure 2. Nevertheless, female individuals seemed to have significantly higher average $\mathrm{Hb} \mathrm{F}$ determined by alkaline $\mathrm{Hb} \mathrm{F}$ measurement than their male counterparts $(P<$ 0.05 , Table 2). This finding was consistent with previous studies in the general population that higher $\mathrm{Hb} \mathrm{F}$ has been

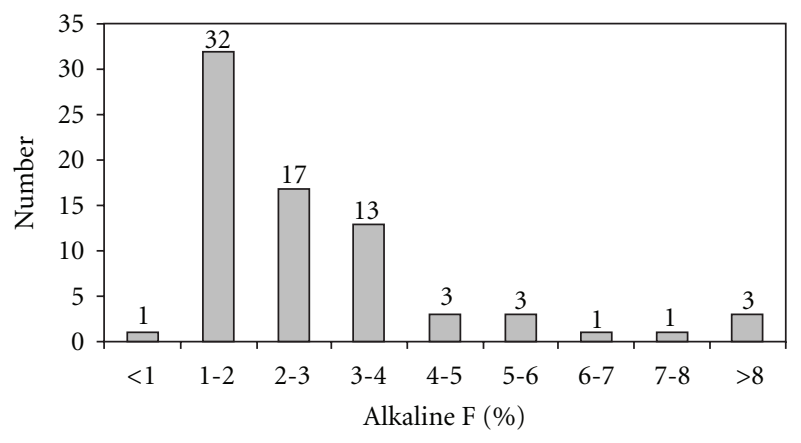

FIGURE 2: Hemoglobin F distribution in 74 individuals with homozygous $\mathrm{Hb} \mathrm{E}$.

observed in female leading to the comprehensive studies on quantitative-trait locus (QTL), including X-linked gene on Xp22.2, for the expression of $\gamma$ globin gene [21-23]. However the main causative mechanism underlying sexual difference remains obscure. Interestingly, hematological data of these homozygous $\mathrm{Hb} \mathrm{E}$ cases with high $\mathrm{Hb} \mathrm{F}$ are not different from those who had less $\mathrm{Hb} \mathrm{F}$ or none (data not shown).

Interestingly, there was no significant association between specific $\beta$ globin haplotypes and Xmn I polymorphism in these eight individuals with high $\mathrm{Hb}$ F compared to the rest. Moreover, we failed to identify any association between eight $\beta$ globin haplotypes and the baseline $\mathrm{Hb} \mathrm{F}$ levels determined by alkaline denaturation in all 74 cases (data not shown). Even though the average alkali $\mathrm{F}$ levels were albeit increased in homozygous $\mathrm{Hb} \mathrm{E}$ with $\mathrm{Xmn}$ I $(++)$ compared to $(+-)$ it was statistically insignificant within the same sex (Table 2).

\section{Discussion}

To the best of our knowledge, this study, herein, provides the most extensive analyses of the $\beta$ globin haplotypes linked to $\mathrm{Hb} \mathrm{E}$ alleles to date. Due to a higher number of individuals with homozygous $\mathrm{Hb} \mathrm{E}$ used in this study, we found that the haplotypes linked to $\mathrm{Hb} \mathrm{E}$ in Thailand might be more heterogeneous than was previously thought. At least 
TABle 2: Comparison of alkaline F \% $( \pm \mathrm{SD})$ in homozygous $\mathrm{HbE}$ with different Xmn I alleles.

\begin{tabular}{lccccc}
\hline $\begin{array}{l}\text { Xmn I } \\
\text { genotype }\end{array}$ & $N$ & $\begin{array}{c}\text { Male } \\
\text { Alkaline F (\%) }\end{array}$ & $N$ & $\begin{array}{c}\text { Female } \\
\text { Alkaline F (\%) }\end{array}$ & $P$ value* \\
\hline$+/+$ & 18 & $2.34 \pm 1.24$ & 24 & $3.38 \pm 0.26$ & $<0.05$ \\
$+/-$ & 10 & $1.93 \pm 0.27$ & 20 & $2.83 \pm 2.5$ & $<0.05$ \\
$-/-$ & 2 & $1,3.5$ & 0 & NA & NA \\
\hline
\end{tabular}

${ }^{*}$ Significantly difference $(P<0.05)$ between male and female subjects with similar Xmn I genotypes. NA: not available.

8 different haplotypes including two novel ones were found in this study; however, in the majority of these cases (94.3\%), $\mathrm{Hb} \mathrm{E}$ alleles were linked with the three major haplotypes; (a) (III), (b) (V), and (c) (IV), consisting with previous studies in our population and supporting the hypothesis of multiple origins of $\mathrm{Hb} \mathrm{E}$ in this part of the world [11-13]. In Bangkok, where it is a melting pot of the whole country due to a massive immigration of people from different parts of Thailand, it is not simple to trace and track back their original regions. Therefore it is not surprising that we found such a heterogeneity including two new haplotypes in Thailand: Th1; $(-----+-)$ and Arab-Indian; (+ $+-+++-)$. The latter is identical to $\beta^{\mathrm{S}}$ haplotype reported from previous studies $[20,24]$. However, these two new haplotypes were closely similar to the two common haplotypes of $\mathrm{b}(\mathrm{V})$ and a (III), respectively. Only the specific restriction site at the $\varepsilon$-Hind II site is different suggesting that these two novel haplotypes may arise from interallelic gene conversion than an independent origin [25]. Moreover our study also confirms the previous construction of the $\beta$ globin haplotypes in other studies which had a limited number of homozygous condition and used the haplotype analyses mainly from $\mathrm{Hb}$ E heterozygotes $[11,12]$.

In this study, we further addressed the correlation between the $\beta$ globin haplotype (implying cis-regulatory sequences) and the predisposition of $\mathrm{Hb} F$ production. We found several individuals with homozygous $\mathrm{Hb} \mathrm{E}$ and high levels of $\mathrm{Hb} \mathrm{F}$ in which other extrinsic factors such as intercurrent infection, hematopoietic stress, and erythropoiesis could not be accounted for. These individuals may provide a novel, rather less complicated natural model for further study on molecular mechanism controlling $\gamma$ globin expression as they all have identical $\beta$ globin gene defects ( $\mathrm{Hb} \mathrm{E}$ ) and their linked $\beta$ globin haplotypes could be easily constructed. However, we did not succeed to identify any positive correlation, even with the Xmn I polymorphism suggesting that $\mathrm{Hb} \mathrm{F}$ production found in these homozygous $\mathrm{Hb} \mathrm{E}$ individuals might be mainly controlled by trans-acting mechanism(s) including HBS1L and BCL11A $[6,26]$. On the contrary, the strong association between the extensive $\beta$ globin haplotypes and clinical severity of $\mathrm{Hb} \mathrm{E} / \beta$ thalassemia patients were found in Thai patients and this was accounted by a link between the probable functional SNP, Xmn I, and the propensity to increase $\mathrm{Hb} F$ production [10]. It is possible that the levels of erythropoietic stress and/or globin imbalance found in our homozygous $\mathrm{Hb} \mathrm{E}$ individuals must be significantly lesser compared to $\mathrm{Hb} \mathrm{E} / \beta$ thalassemia and this might not be enough to trigger the switching of postnatal $\gamma$ globin expression as the $\mathrm{Hb} \mathrm{E} / \beta$ thalassemia syndrome does. Interestingly, our study showed that $\mathrm{Hb} \mathrm{E}$ alleles in our study population are linked to both $\mathrm{T}(+)$ and $\mathrm{C}(-)$ alleles of the Xmn I site suggesting a high heterogeneity of $\mathrm{Hb} \mathrm{E}$ alleles within Thai population and highlighting a great consideration for future determination of haplotype and SNPs, which links to the phenotypes related to $\mathrm{Hb} F$ and clinical severity.

In conclusion, the association of $\mathrm{Hb} \mathrm{F}$ production with the Xmn I and the $\beta$ globin haplotypes as a marker could not be confirmed using homozygous $\mathrm{Hb} \mathrm{E}$ condition. However, this might suggest a limitation of the model used in this study as the influence of cis-regulatory elements might not be strong enough to be detected under a condition with slighter hematopoietic stress such as homozygous $\mathrm{Hb} \mathrm{E}$.

\section{Conflict of Interests}

The authors declare no conflict of interests.

\section{Authors' Contribution}

V. Viprakasit was the principal investigator and was primarily responsible for the design and analysis of the study. S. Ekwattanakit and Y. Monteerarat performed all molecular studies and were involved in interpretation of data; $\mathrm{S}$. Ekwattanakit also performed statistical analyses and draft of the paper. K. Tachavanich and S. Riolueang performed hematological analysis and collected all patients' data. All authors read and approved the final version of the paper.

\section{Funding Source}

This paper was supported by a grant from the Thailand Research Fund through the Royal Golden Jubilee Ph.D. Program (Grant no. PHD/0089/2548) to S. Ekwattanakit and V. Viprakasit. SE is also supported by a grant from Department of Immunology (Ph.D. program), Faculty of Medicine Siriraj Hospital, Mahidol University, Bangkok, Thailand. Y. Monteerarat is supported by Medical Scholar Program, Mahidol University. This work is supported by Thailand Research Fund and BIOTEC, National Science and Technology Development Agency (NASDA), and National Research University (NRU) Grant through Mahidol University, Thailand to V. Viprakasit.

\section{Acknowledgments}

The authors would like to thank all individuals with homozygous $\mathrm{Hb} \mathrm{E}$ who participated in this study. The authors thank Worrawut Chinchang and Waraporn Glomglao for their excellent technical assistance.

\section{References}

[1] D. J. Weatherall and J. B. Clegg, Eds., The Thassaemia Syndromes, Blackwell Science, Oxford, UK, 4th edition, 2001. 
[2] S. Fucharoen and P. Winichagoon, "Clinical and hematologic aspects of hemoglobin E $\beta$-thalassemia," Current Opinion in Hematology, vol. 7, no. 2, pp. 106-112, 2000.

[3] S. Fucharoen, P. Winichagoon, P. Pootrakul, A. Piankijagum, and P. Wasi, "Variable severity of Southeast Asian beta 0thalassemia/Hb E disease," Birth Defects Original Article Series, vol. 23, no. 5A, pp. 241-248, 1987.

[4] S. Fucharoen, P. Ketvichit, P. Pootrakul, N. Siritanaratkul, A. Piankijagum, and P. Wasi, "Clinical manifestation of $\beta$-thalassemia/hemoglobin E disease," Journal of Pediatric Hematology/Oncology, vol. 22, no. 6, pp. 552-557, 2000.

[5] V. Viprakasit, V. S. Tanphaichitr, W. Chinchang, P. Sangkla, M. J. Weiss, and D. R. Higgs, "Evaluation of alpha hemoglobin stabilizing protein (AHSP) as a genetic modifier in patients with $\beta$ thalassemia," Blood, vol. 103, no. 9, pp. 3296-3299, 2004.

[6] V. G. Sankaran, T. F. Menne, J. Xu et al., "Human fetal hemoglobin expression is regulated by the developmental stage-specific repressor BCL11A," Science, vol. 322, no. 5909, pp. 1839-1842, 2008.

[7] J. Jiang, S. Best, S. Menzel et al., "cMYB is involved in the regulation of fetal hemoglobin production in adults," Blood, vol. 108, no. 3, pp. 1077-1083, 2006.

[8] P. Sebastiani, L. Wang, V. G. Nolan et al., "Fetal hemoglobin in sickle cell anemia: bayesian modeling of genetic associations," American Journal of Hematology, vol. 83, no. 3, pp. 189-195, 2008.

[9] C. Garner, T. Tatu, J. E. Reittie et al., "Genetic influences on F cells and other hematologic variables: a twin heritability study," Blood, vol. 95, no. 1, pp. 342-346, 2000.

[10] Q. Ma, K. Abel, O. Sripichai et al., “ $\beta$-Globin gene cluster polymorphisms are strongly associated with severity of $\mathrm{HbE} / \beta 0$ thalassemia," Clinical Genetics, vol. 72, no. 6, pp. 497-505, 2007.

[11] G. Fucharoen, S. Fucharoen, K. Sanchaisuriya et al., "Frequency distribution and haplotypic heterogeneity of $\beta \mathrm{E}$ globin gene among eight minority groups of northeast Thailand," Human Heredity, vol. 53, no. 1, pp. 18-22, 2002.

[12] P. Yongvanit, P. Sriboonlue, N. Mularlee et al., "DNA haplotypes and frameworks linked to the $\beta$-globin locus in an Austro-Asiatic population with a high prevalence of hemoglobin E," Human Genetics, vol. 83, no. 2, pp. 171-174, 1989.

[13] S. E. Antonarakis, S. H. Orkin, H. H. Kazazian Jr. et al., "Evidence for multiple origins of the $\beta(\mathrm{E})$-globin gene in Southeast Asia," Proceedings of the National Academy of Sciences of the United States of America, vol. 79, no. 21, pp. 6608-6611, 1982.

[14] K. Tachavanich, V. Viprakasit, W. Chinchang, W. Glomglao, P. Pung-Amritt, and V. S. Tanphaichitr, "Clinical and hematological phenotype of homozygous hemoglobin E: revisit of a benign condition with hidden reproductive risk," Southeast Asian Journal of Tropical Medicine and Public Health, vol. 40, no. 2, pp. 306-316, 2009.

[15] K. Betke and E. Kleihauer, "The acid elution technique and the question of the influence of membrane qualities on its results," Annales de la Societe Belge de Medecine Tropicale, vol. 49, no. 2, pp. 151-156, 1969.

[16] N. J. Goulden and C. G. Steward, Pediatric Hematology: Methods and Protocols, Humana Press, Totowa, NJ, USA, 2004.

[17] M. Stephens, N. J. Smith, and P. Donnelly, "A new statistical method for haplotype reconstruction from population data," American Journal of Human Genetics, vol. 68, no. 4, pp. 978989, 2001.
[18] M. Stephens and P. Donnelly, "A comparison of bayesian methods for haplotype reconstruction from population genotype data," American Journal of Human Genetics, vol. 73, no. 5, pp. 1162-1169, 2003.

[19] S. H. Orkin, H. H. Kazazian Jr., S. E. Antonarakis et al., "Linkage of $\beta$-thalassaemia mutations and $\beta$-globin gene polymorphisms with DNA polymorphisms in human $\beta$ globin gene cluster," Nature, vol. 296, no. 5858, pp. 627-631, 1982.

[20] R. L. Nagel and H. M. Ranney, "Genetic epidemiology of structural mutations of the $\beta$-globin gene," Seminars in Hematology, vol. 27, no. 4, pp. 342-359, 1990.

[21] M. A. F. El-Hazmi, A. S. Warsy, M. H. N. Addar, and Z. Babae, "Fetal haemoglobin level-effect of gender, age and haemoglobin disorders," Molecular and Cellular Biochemistry, vol. 135, no. 2, pp. 181-186, 1994.

[22] K. Miyoshi, Y. Kaneto, H. Kawai et al., "X-linked dominant control of F-cells in normal adult life: characterization of the Swiss type as hereditary persistence of fetal hemoglobin regulated dominantly by gene(s) on X chromosome," Blood, vol. 72, no. 6, pp. 1854-1860, 1988.

[23] G. J. Dover, K. D. Smith, Y. C. Chang et al., "Fetal hemoglobin levels in sickle cell disease and normal individuals are partially controlled by an X-linked gene located at Xp22.2," Blood, vol. 80, no. 3, pp. 816-824, 1992.

[24] G. V. Ramana, G. R. Chandak, and L. Singh, "Sickle cell gene haplotypes in Relli and Thurpu Kapu populations of Andhra Pradesh," Human Biology, vol. 72, no. 3, pp. 535-540, 2000.

[25] S. K. Das and G. Talukder, "A review on the origin and spread of deleterious mutants of the $\beta$-globin gene in Indian populations," HOMO_Journal of Comparative Human Biology, vol. 52, no. 2, pp. 93-109, 2001.

[26] M. Nuinoon, W. Makarasara, T. Mushiroda et al., "A genomewide association identified the common genetic variants influence disease severity in $\beta 0$-thalassemia/hemoglobin E," Human Genetics, vol. 127, no. 3, pp. 303-314, 2010. 


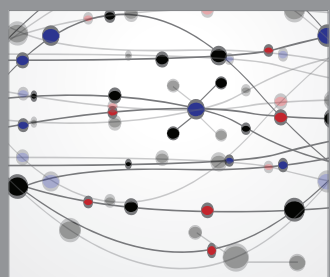

The Scientific World Journal
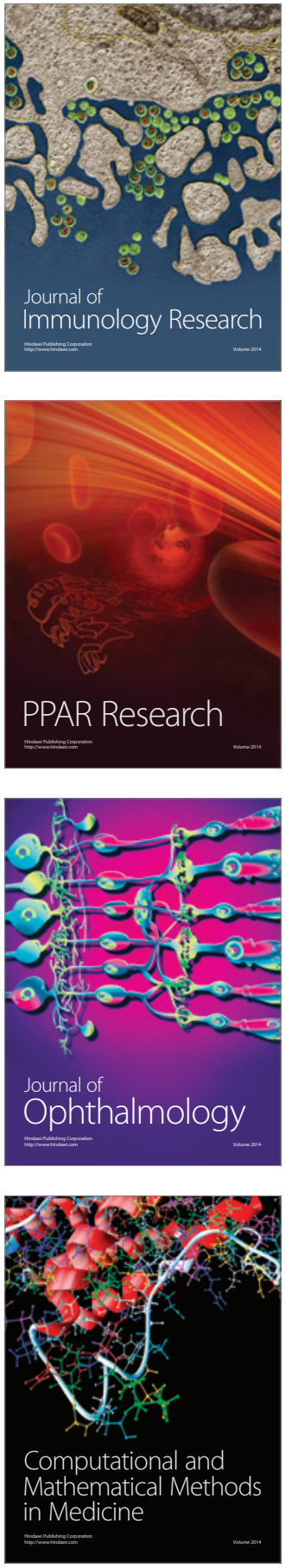

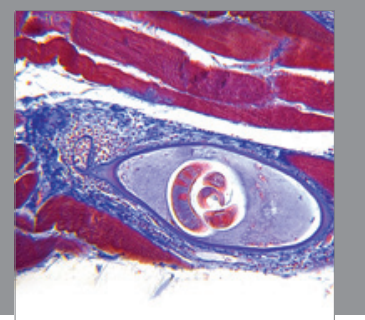

Gastroenterology

Research and Practice
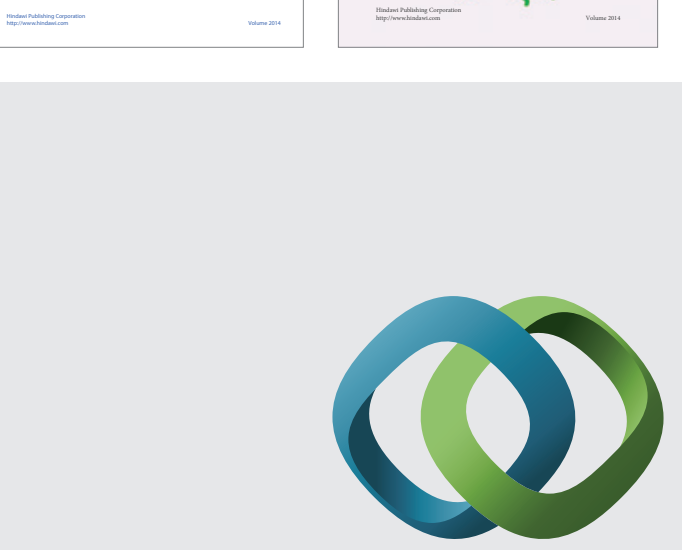

\section{Hindawi}

Submit your manuscripts at

http://www.hindawi.com
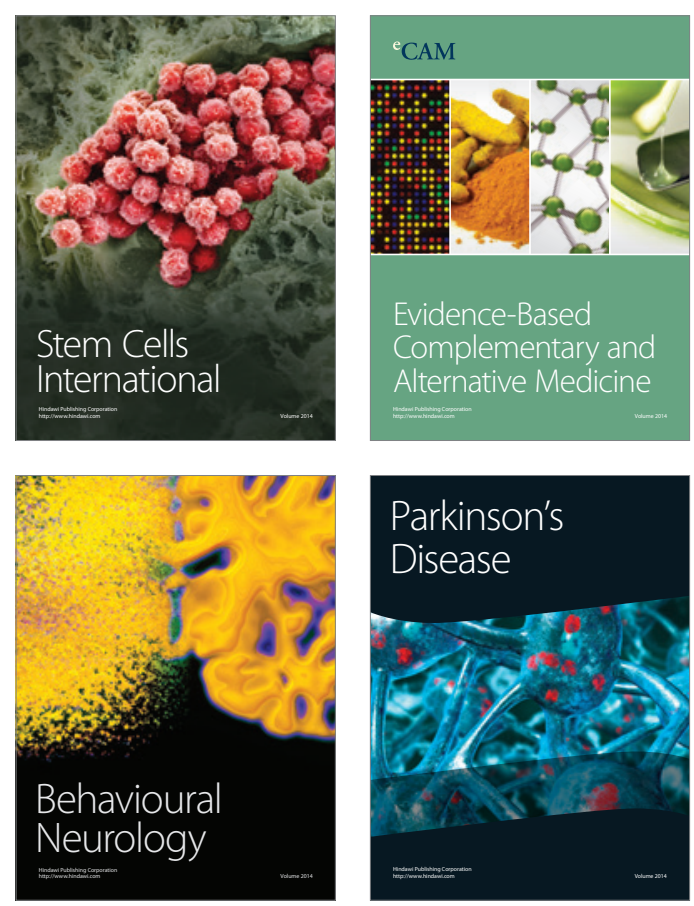

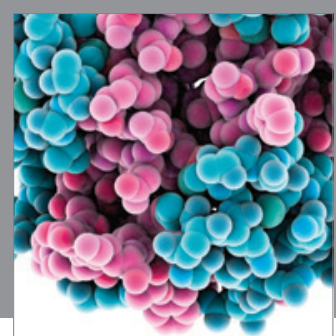

Journal of
Diabetes Research

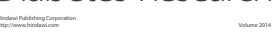

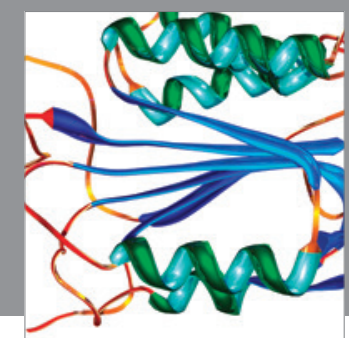

Disease Markers
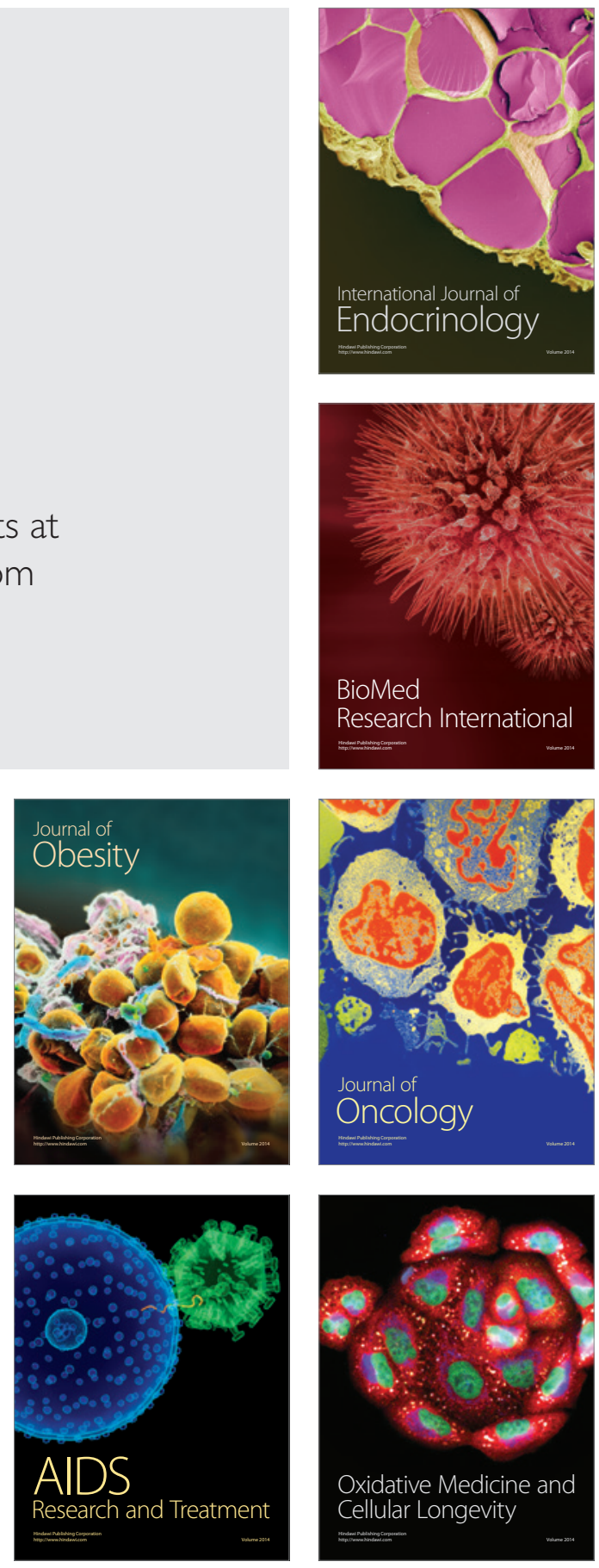